The International Journal of Engineering and Science (IJES)

|| Volume || 6 || Issue || 4 || Pages || PP 07- 14 || 2017 ||

ISSN (e): $2319-1813$ ISSN (p): $2319-1805$

THE IJES

\title{
Geological-Geotechnical Characterization of the elements, of Luanda Soils, Angola, for Geotechnical Cartography through Analysis of Variability Space of N (Spt) results
}

\author{
${ }^{1}$ Gabriela Jeremias Pereira Teixeira Pires , ${ }^{2}$ Héctor Manuel Fernández Núñez \\ ${ }^{1}$ Department of Geology, Sciences Faculty of Agostinho Neto University, Avenida 4 de Fevereiro, 71, \\ BP-815, Luanda, Angola \\ ${ }^{2}$ Instituto Superior Politécnico "José A. Echeverría” Calle 124 s/n, Marianao 15, Ciudad de La \\ Habana, Cuba
}

\begin{abstract}
The knowledge of soil behavior and conditions in subsurface is essential for the development of projects, through the resistance properties obtained in the dynamic penetration test. The frequency by which SPT (Standard Penetration Test) Field tests, and Laboratory tests are carried out in urban area is large, and the volume of results makes possible to acquire a great deal of geological and geotechnical information of great importance for the design of various types of Engineering works. The real target of this study are the different lithostratigraphic units that include the surface soils and the soil of the substrate of a part of Luanda province.

The aim of this work is to present the distribution based on substrate depth starting from the analysis and treatment of results of SPT in urban area as an element to be taken into account in the requalification and reordering. Activities that are currently taking place in order to use and occupy rational aspects that prove to be very useful when seeking solutions that reach levels of safety, economy and optimization of cost versus benefit.

In addition, the present work constitutes also, an approach on the importance of Geology in the planning of the city of Luanda and its surroundings.
\end{abstract}

Keywords: Geotechnical cartography, spatial planning, substrate depth, SPT

Date of Submission: 10 April 2017

Date of Accepted: 22 April 2017

\section{INTRODUCTION}

The contents of each section may be provided to understand easily about the paper. At present, the city of Luanda has been the target of several interventions since the urban equipment for the construction of urban buildings (housing, hospital and school units), and other public utilities or even the rehabilitation of basic sanitation structures and road network. All the activities take place in the physical space of the soils which, beyond acting as support for the development of those actions are also used as building materials.

New construction works are always preceded by geological-geotechnical reconnaissance studies and, in the case of a city, the volume of information is immense, as it is seen in the amount of so many Reports.

In the study of the soil - soil and subsoil - the geotechnical geological reconnaissance campaigns are carried out through drilling and different tests. Among them, the most frequent is the Dynamic Penetration Test or SPT (Standard Penetration Test).

These tests are very widespread and the results are used for the characterization, delimitation and geotechnical zoning (Almeida, 1991); for the recognition and design of works for the geotechnical cartography (Coelho, 1980), (Câmara \& Pereira, 2000) due the set of information and its results lead to generation of maps (Folle, 2002).

These tests are also used in the prospection of Luanda soils since 1957 (Riccardi, 1957). Their results are reported in different Institutions and Organisms and its information serves to know the depth of the substrate to take into account when defining areas for development of new urbanizations, in this case to predefine the type of foundations. 


\section{MATERIALS AND METHOD}

The area of this study does part of the province of Luanda, capital of Angola, which integrates the Municipality of Luanda and its surroundings, with the following coordinates: Latitudes: $8^{\circ} 44^{\prime} 30^{\prime \prime} \mathrm{S}$ e $8^{\circ} 58^{\prime} 22^{\prime \prime} \mathrm{S}$ Longitudes $13^{\circ} 07^{\prime} 22^{\prime \prime} \mathrm{E}$ e $13^{\circ} 22^{\prime} 42^{\prime \prime} \mathrm{E}$ (Fig 1)

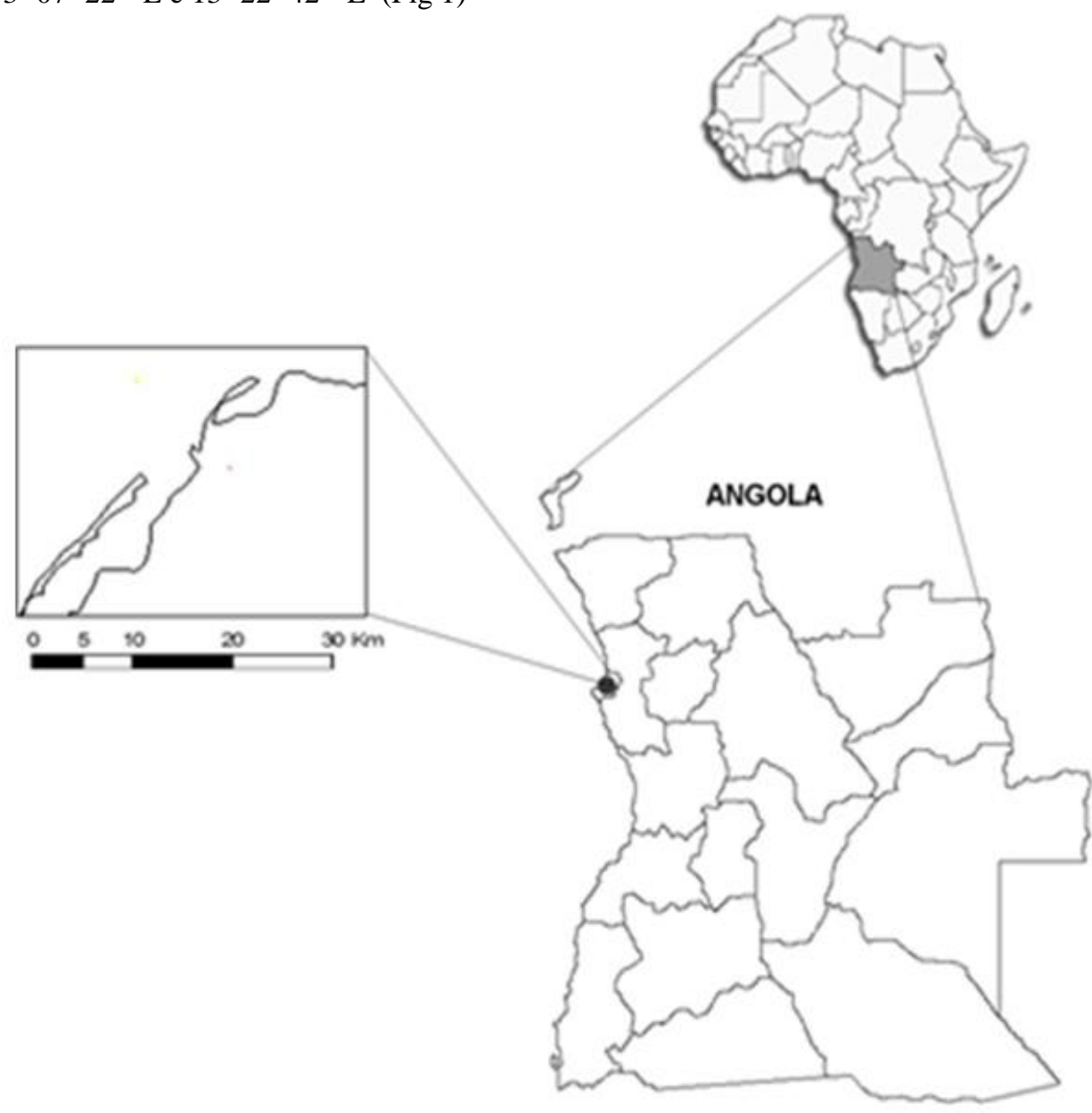

Figure 1. Location of the study area

The SPT has been used preferably throughout the world as an indispensable tool in preliminary investigations for foundations soils Projects, due the simplicity, robustness and fast response time. It is reasonable to look for means that allow a more reliable evaluation of its performance: the «soil» through a standardized procedure.

The SPT test is performed in drill holes and consists of the drilling of a standard sample with a minimum length of $45 \mathrm{~cm}$ at a weight of $63.5 \mathrm{~kg}$ with a height of $75 \mathrm{~cm}$. The test, practically is performed in two stages. In the first phase, the number of strokes corresponding to $15 \mathrm{~cm}$ of penetration is recorded. The results obtained are neglected, because it is considered that the most superficial part of the massif is disturbed, due to the opening of the hole. In the second phase of the test, the number of strokes $\mathrm{N}$, corresponding to the penetration of $30 \mathrm{~cm}$ is recorded, which indicates the strength of the mass in situ. Even if the total penetration of the sample has not been achieved, the test usually ends when 50 or 60 strokes are reached in one of the phases. 


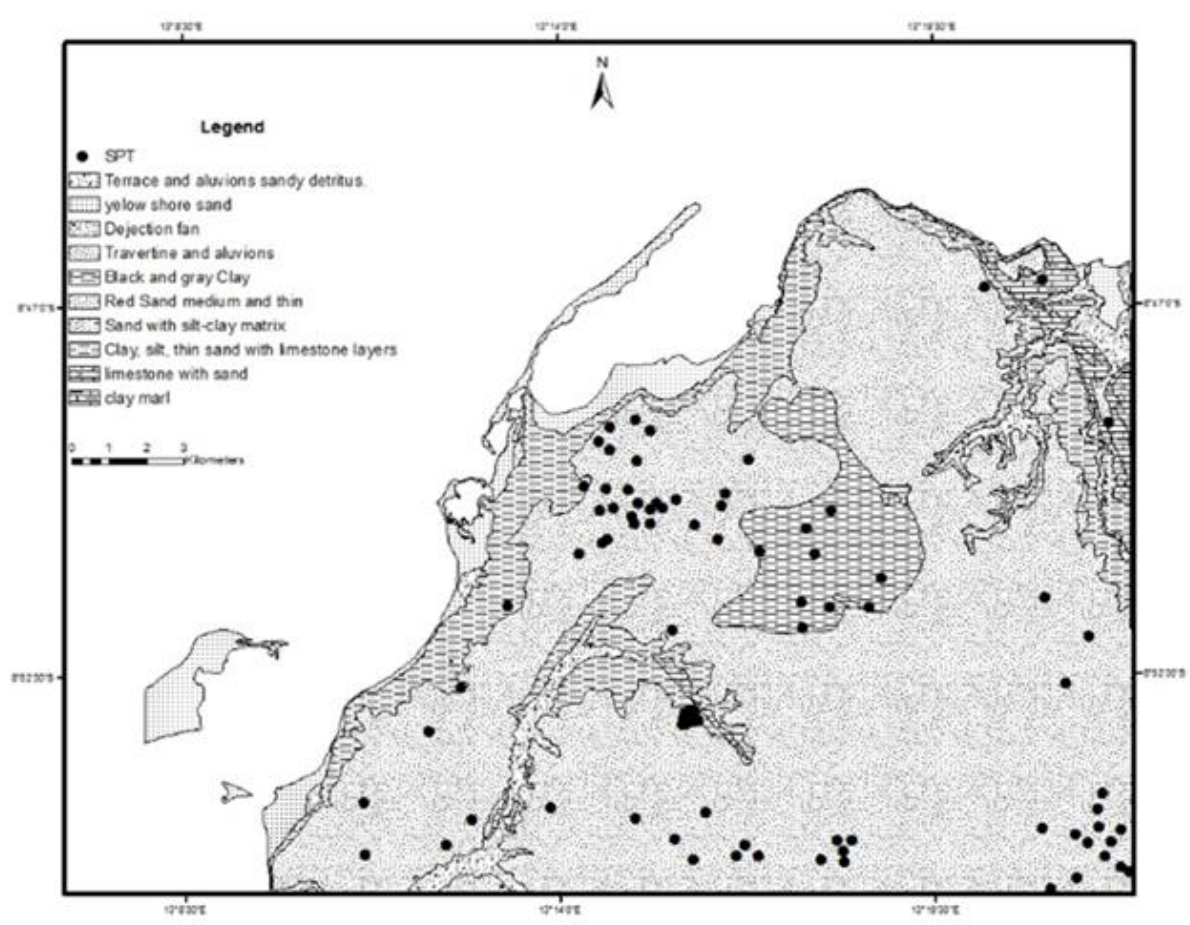

Figure 2. Map of lithological units and SPT test point

The SPT test was partially normalized by ASTM D1586-63T and presently by ISSMFE-T16, 1989. The value presented for each sub-phase of the 2 nd phase is 50 strokes connected to the length of the penetration obtained in each of them (Lopes, 2000).

The depth intervals among the tests are defined in the specifications, but it is usual to carry out intervals of 1,5 meters or when there is a change in lithology. The probing and testing end by reaching 2 or 3 consecutive essays with the previously established $\mathrm{N}$ (nega) value.

The situations related to this test are when the penetration obtained in the 2 nd phase is less than $30 \mathrm{~cm}$, and the other situation is when the penetration obtained in the $1 \mathrm{st}$ phase is less than $15 \mathrm{~cm}$. In these cases, where the regulated penetration is not reached, a proportional operation is carried out obtaining in this way an extrapolated value, corresponding to the penetration of $30 \mathrm{~cm}$. The limits established and considered to be terminated may be related to the $\mathrm{N}$ correlations with the simple and strength compression of coherent soils and the relative compactness of sands that are commonly used Terzaghi and Peck, (1967, in: Marques, 1988).

According to ASTM 1566-64T, the standards or procedures for performing assays may vary, an example: when the limit value of the second phase is 100 - it was verified in the tests carried out in Macao - for the soils resulting from the altered granites. In this standard, values greater than 100 are allowed, and the test finished when the penetration is less than 1 inch $(2.54 \mathrm{~cm})$ in every 50 strokes (Marques, 1988).

The SPT tests are used in the geotechnical surveys of Luanda soils since the 1950s, as it is shown in the article published by Riccardi (1957), referring to their realization in the surveys of the Marginal soils on Avenida 4 de Fevereiro. Practically in Angola, the test ends in general, after 60 strokes, but we found some tests ended after 50 strokes, and in some Companies were adopted 100 strokes.

The aspects related to the correction of $\mathrm{N}$ were not applied in the present work because we did not know not only the characteristics of the applied equipment but also the characteristics of the set of elements that were used in the tests and, moreover, the circumstances in which they were performed were not known. The present results are not intended to interpret in a qualitative and semi - quantitative perspective for the resistance to penetration of the different lithologies of the units intercepted in the surveys.

The frequency with which the SPT was performed allowed the acquisition of a large volume of geological and geotechnical information, which is applied in the characterization at small and regional levels, and is of great importance for the design of various types of Engineering works and Planning. First, preexisting data were collected with pertinent information to the evaluation of the $\mathrm{N}$ distribution (SPT) of the study area.

For this study were collected information and data from the main sources such as: geological geotechnical with results of drillings, SPT and Laboratory tests. Most of the information was obtained from the Angolan Engineering Laboratory (LEA) and from another Company: «GEOTÉCNICA-UEE». The type of information 
used is shown in figure 2. This work phase was corroborated with results obtained from samples tested during this study (PIRES, 2007).

The considered units are differentiated from a lithogeological point of view, with lithology and genesis are pointed out by the main factors for the definition of the homogeneity domains. The lithological units are subdivided in surface units that include beach sands (ap), landfills (A), alluviums (al), deposits of slope (a3), dejection cones (a2), recent alluviums (a1), Cazenga clays (Q3), Red Sands (Q2) and, Gray Sands (Q1). The substrate units include a mix of Luanda sands, clays and silts (p1), decomposed limestones and Cacuaco limestones (m1c) and, the Quifangondo clays and marls (m1), Figure 2. The composition of the soils in the considered units is differentiated through the lithogeological point of view, being the lithology and genesis the main factors for the definition of the homogeneity domains. Considering the distribution of soil groups in each of the geotechnical units, according to textural, AASHTO (E 240-1970) and, Unified (ASTM D 2487-85) classifications, the most frequent soil groups were presented in this paper (Pires et. al., 2016).

\section{RESULTS AND DISCUSSIONS}

Landfills (A) consist of heterogeneous materials, sandy, sandy and pebble, these deposits are found on the beach sands, on slope deposits or on fluvial marine sediments and constitute the ground levelling in downtown. The thickness of this set varies between 2 and $5 \mathrm{~m}$, reaching less than $9 \mathrm{~m}$. The results of the SPT tests at these places provided maximum values equal to and less than 20 . Up to $2 \mathrm{~m}$ depth, the values vary from $4 \leq \mathrm{N} \leq 20$. At $3 \mathrm{~m}$; the maximum values were recorded with $\mathrm{N}=20$ and minimum with $\mathrm{N}=2$. From 4 to $7 \mathrm{~m}$ which was the maximum thickness recorded for landfills, in accordance with the data and available information from the reports, where $\mathrm{N}$ values were equal to or lower than 10 . In the case of incoherent soils regarding to compactness, landfills are very loose to moderately compact.

The beach sands (ap) occupy a strip along the coast and are constituted by heterogeneous sands, clean of varied granulometry, often with fragments of shells. The deposits reach thicknesses in the order of two tens of meters in Luanda Island, reaching $5 \mathrm{~m}$ along the coast.

The slope deposits (dv) are composed by materials from the adjacent cliffs, with heterogeneous materials derived from the disaggregation, transported and deposited in the rainy season. They occupy the bottom of the slopes and are located in downtown. The dejection Cones (a2) are the units constituted by sands and pebbles and occupy restricted areas at the mouth of the water lines. The oldest alluvial deposits (al) occupy the ground of low elevations. They are composed by fluvial marine sediments, with sands of varied granulometry and clays. According to the description of the survey profiles, the fluvial (al) and fluvial alluvial deposits are essentially sandy, with sand, washed sands, medium and coarse sands, silty sands and silty clay sands. The distribution of the results of the SPT tests shows alluviums are composed of loose materials $(\mathrm{N} \leq 10)$ up to $4 \mathrm{~m}$, medium compact $(10 \leq \mathrm{N} \leq 30)$ and barely with medium compactness $(\mathrm{N} \leq 40)$. These deposits have thicknesses less than $8 \mathrm{~m}$.

Recent alluvium deposits (a1) are deposits with heterogeneous sediments with sands and pebbles; they are found in the bottom of the Cambamba and Cambolombo river valleys at north of Luanda. These deposits are also found in the bottom of the Mulenvos and Leito Corte valleys, in «Mulenvos de Baixo».

The results of the SPT tests on the Cazenga Clays provided maximum values equal to and less than 20 in the case of incoherent soils in terms of compactness, are very loose to medium-compact soils. The thickness of this unit, is of the order of $5 \mathrm{~m}$, according to the drillings made in the central part of this unit what allowed to obtain and know the depth thickness of the substrate. The results of the SPT tests, from $0.5 \mathrm{~m}$ have shown values between $(15 \leq \mathrm{N} \leq 26)$ being essentially argillaceous, forming hard, hardest soils. The most superficial layers of this unit are hardened and, are observed on almost surface of the outcrop. $\mathrm{N}$ values between 28 and 40, are also present corresponding to very hard soils with rigid consistency.

The distribution of the $\mathrm{N}$ values (SPT) in the Sands of Quelo (Figure 3.), through the analysis of statistical parameters (mean, modal and median), provide indications of the compactness in the different depth intervals. From $2 \mathrm{~m}$ to $4 \mathrm{~m}, \mathrm{~N}$ values were recorded at all intervals, even on $\mathrm{N} \leq 60$ values. In this interval, the highest frequency was $3 \leq \mathrm{N} \leq 10$. The median points to values indicating loose soils and the model indicates moderately compact soils. The values of $\mathrm{N}$, above 60 were recorded in the tests carried out in the New Urbanization of Golf and in the University City (Camama). From $4 \mathrm{~m}$, there is an increase in the frequency for $\mathrm{N}$ values equal to or greater than 60. Up to $6 \mathrm{~m}$, there is an increase in $\mathrm{N}$ values, which occur in the mean, mode and median, even with the reduction of the tests $(\mathrm{N})$. There is an increase from $6 \mathrm{~m}$ where the values of $\mathrm{N}$ equal and superior to 60 become more frequent, with a decreasing frequency in the previous intervals. From 8 to $10 \mathrm{~m}$, the increasing goes on in the frequency with $\mathrm{N} \geq 60$ up to $15 \mathrm{~m}$, which corresponds to the maximum thickness recorded in this unit. 


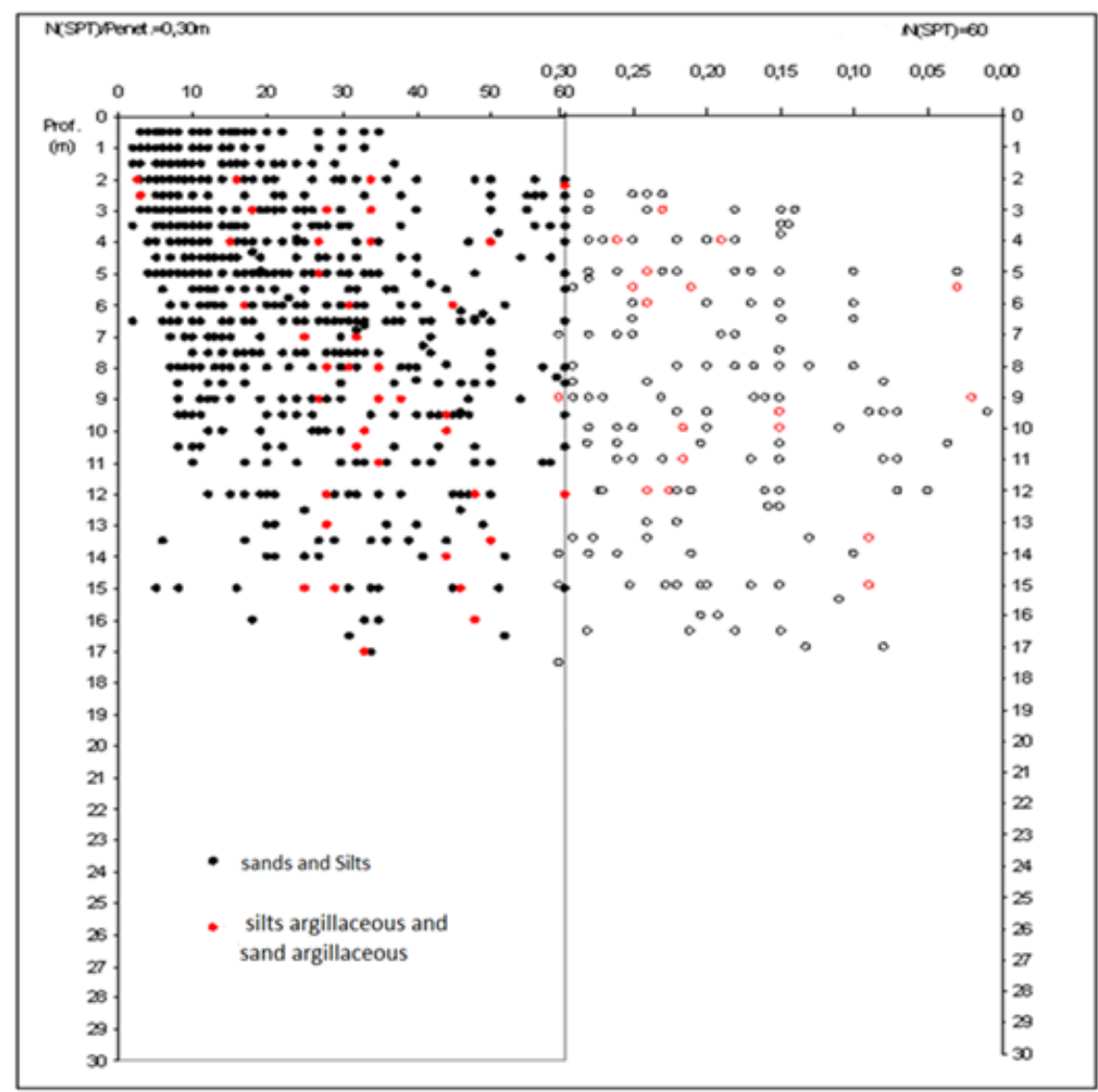

Figure 3. Distribution chart of $N$ results versus depth in Sands of Quelo

The sands, silts and clays of Luanda (Figure 4) form the substrate and lie under the Sands of Quelo. The thickness of these soils is heterogeneous reaching higher values such several tens of meters. This thickness shows a lot of heterogeneity, a fact observed in the record logs. The clays and intercalations of sandstones and limestones witness episodes of transgression because the predominance of marine facies. From the results of the SPT tests and the results analysis, it was found that, from $0.5 \mathrm{~m}$ were recorded values at all intervals, including $\mathrm{N}$ values equal to or greater than 60 . The most frequent values were observed in the range $20 \leq \mathrm{N} \leq 30$.

The surface materials are sand, silty sands, clay sands and argillaceous silt sands, according to the lithology described in the drilling logs. These are incoherent materials, where compact soils are in predominance. In the intercalations with sandstones, calcareous and limestones the values $\mathrm{N}$ are higher than 60 . Between 2 and $4 \mathrm{~m}$, the values are recorded at all intervals and the one with the highest frequency is the range of $10 \leq \mathrm{N} \leq 20$. Values with $\mathrm{N} \geq 60$, with the same frequency were also recorded. There is dispersion in the results related to the large lateral variety of lithology. From $4 \mathrm{~m}$, the most frequent $\mathrm{N}$ values are $\mathrm{N} \geq 60$. These values were most frequently observed in the Golf Urbanization and University City tests, sometimes during the first phase of the test. The results of the surveys carried out in the city center show that these units are intercepted from $8 \mathrm{~m}$. In these areas, the drills are performed until they reach $\mathrm{N}=60$. At least three tests were carried out and they reach the preestablished depths, because in these cases it is common to record values that correspond to very loose materials. Values greater than 60 strokes were recorded at depths less than $4 \mathrm{~m}$ in the tests conducted in the districts of Golfe, Camama and Viana, an area corresponding to Luanda with compact and very compact soils with good characteristics of resistance.

The lithology has values of 6 and values of more than 50 for sands between 10 and 40, fairly to medium compact and very compact sands, when greater than 50. Very low values were recorded in the sands, at $16 \mathrm{~m}$ depth corresponding to loose materials. The clays were detected from $2 \mathrm{~m}$ and constitute lenses between sandy and silt strata. The important layers of silt clays were intercepted in Maianga drillings, with thicknesses of approximately $9 \mathrm{~m}$. From $14 \mathrm{~m}$, where they have very reduced thicknesses of about $0.5 \mathrm{~m}$, they intercalated with limestones. Layers of sandy clays, silty clays were also detected in some surveys conducted in the Luanda-South zone and the Camama area. 


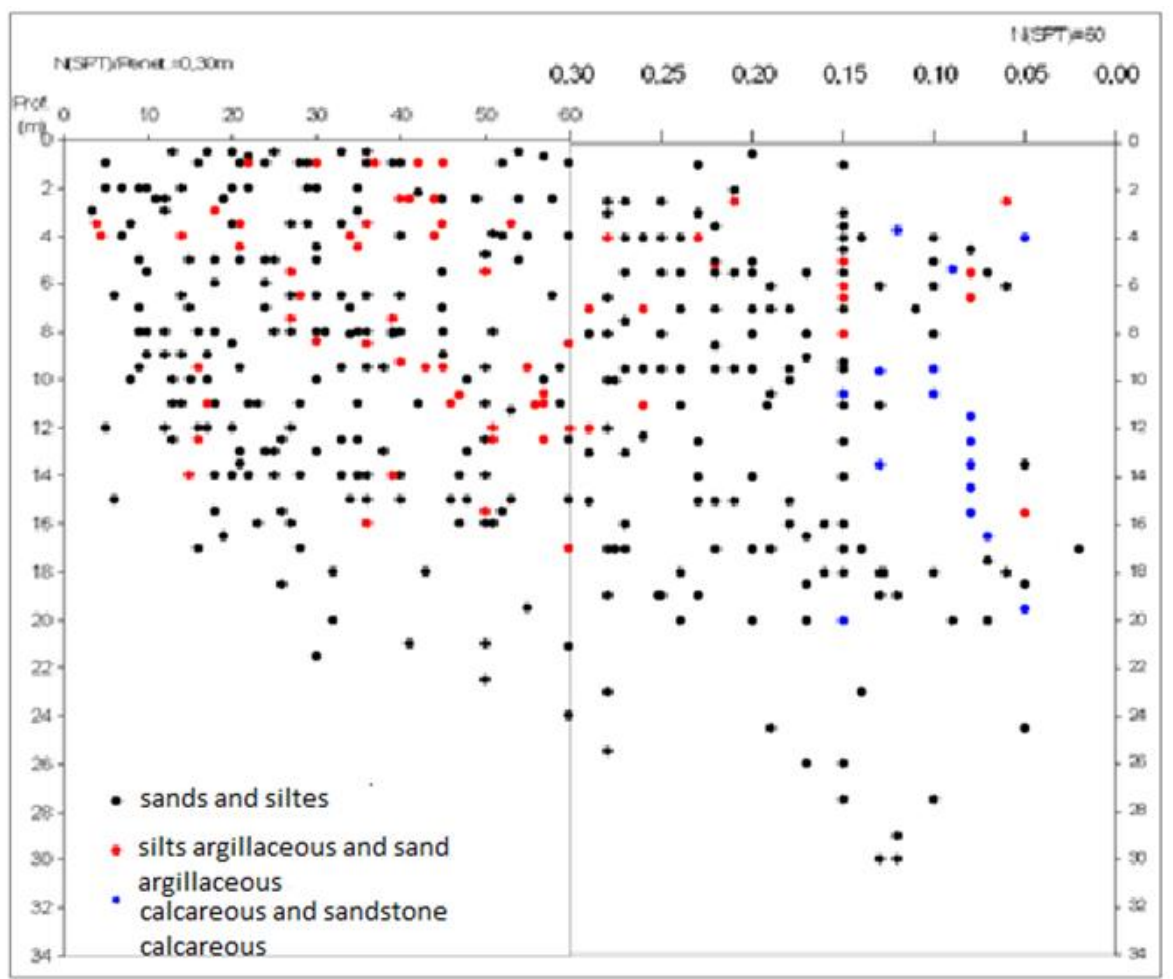

Figure 4 Distribution chart of the results of $\mathrm{N}$ versus depth in the Sands, Silts and Clays of Luanda

Cacuaco limestones include soils with decomposed limestones and calcareous rocks and lie behind the unity of the Cazenga Clays. The rocks occur along the coast, north of the city of Luanda, from Porto Pesqueiro to Farol das Lagostas. In the SPT trials, were recorded 24 and 50 strokes and sometimes more than 60 . The largest exposure of these units was in S. Pedro da Barra and the Quarry of SECIL, whose raw material is used in the manufacture of cement. The soils correspond to small terrains in the Palanca and Golfe neighborhoods. In Cacuaco, small fragments appear near the valleys of Leito Corte and Mulenvos.

"Quifangondo Clays and Marls" are essentially argillaceous soils with high to very high plasticity. The outcrops of these soils correspond to very small areas or, are at great depths not reached by geotechnical prospecting works in the area covered by this work.

Alluvial deposits have characteristics of low resistance and surface water levels, with implications either in the load capacity or in the conditions of works that require the lowering of the water table. Landfills, relatively thin, are not considered as foundation soil. In the case of buildings, the foundations must be deep. Cazenga Clays, with thicknesses that can exceed $5 \mathrm{~m}$, may present limitations, such as land for direct foundations. In the case of installation of buildings, the foundations must be deep.

The SPT tests in the "Sands of Quelo" recorded different values on the surface, up to $2 \mathrm{~m}$ deep. The most frequent values are less than 10: very loose soils and less than 37 that correspond from loose to compact soils (Figure 5). Between 2 and $4 \mathrm{~m}$ of depth, were registered values in all the intervals, being still predominant the very loose and loose soils. There were values of $\mathrm{N}$ between 10 and 30, medium compact soils and values of $\mathrm{N}$ higher than 60, very compact soils. Starting from $6 \mathrm{~m}$ depth, $\mathrm{N}$ values are observed at all intervals, very loose and loose soils to very compact soils. From $8 \mathrm{~m}$, loose soils become less frequent and medium to very compacted soils become frequent till to $16 \mathrm{~m}$ of depth, which corresponds to the maximum thickness recorded in the drilling but it does not always mean the presence of the substrate, because some drillings necessarily had to cross this unit completely, even to the most resistant units. The sands of Quelo represent soils where it is possible to perform works using various types of foundations.

The "Sands, silts and clays of Luanda" recorded values of $\mathrm{N}$ at all intervals up to $2 \mathrm{~m}$, which reflect the compactness of this unit (Figure 6). This is due to the presence of levels with less resistant layers, and strata of loose sands, with very low resistance and intercalations of limestones, sandstones and calcareous that present greater resistance. 


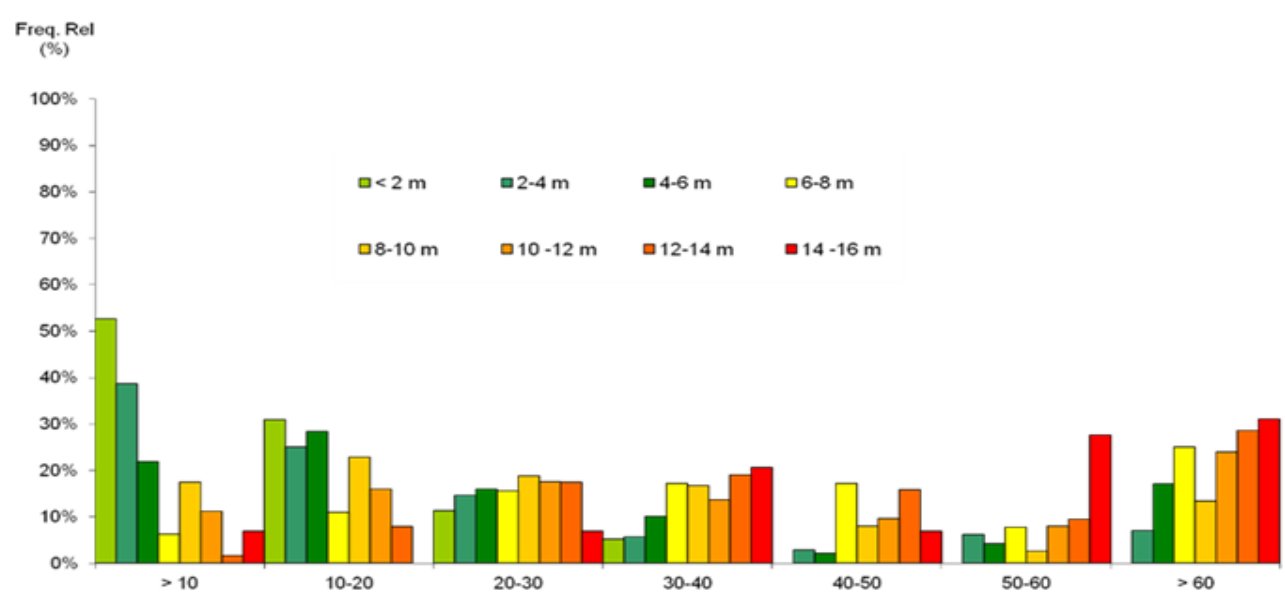

Figure 5. Histogram distribution results in "Sands of Quelo"

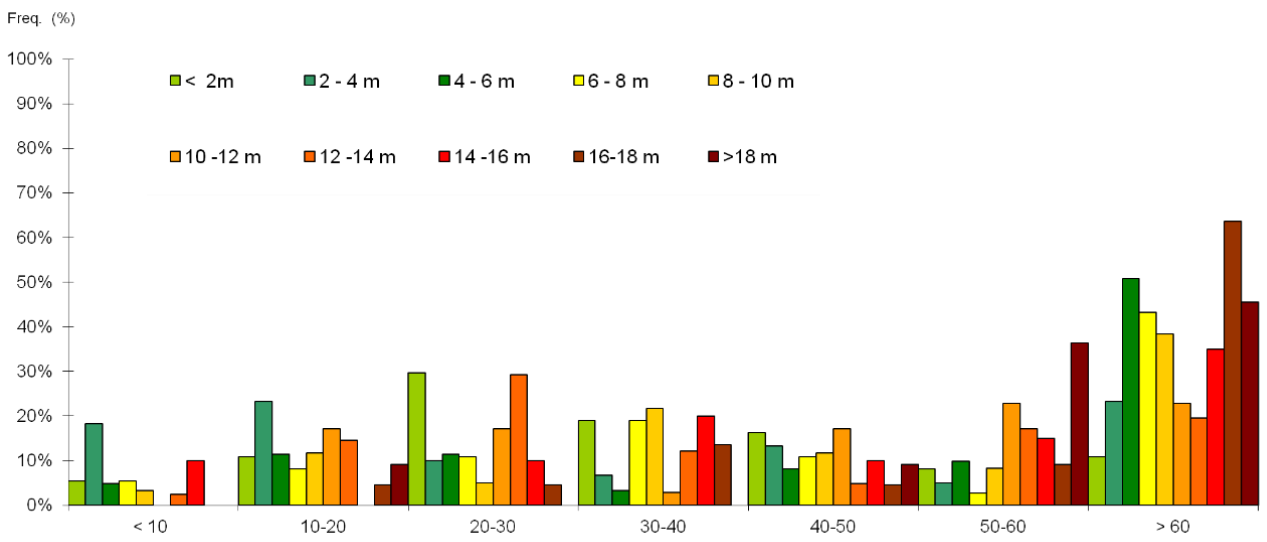

Figure 6. Histogram distribution results in "Sands, Silts and Clays of Luanda"

\section{CONCLUSION}

In this work were presented the geological and geotechnical characteristics of Luanda soils through the results of SPT, to evaluate the behavior of its soils with respect to the depth, according to the different classifications of the soils and its predominant groups, in each lithostratigraphic unit, with the proposal to identify the depth of the substrate.

The diversity of factors involved in this type of approach requires successively more elaborate analysis, due the presence of an expanding urban area, where the existing information needs to be constantly updated.

The use of databases, accessible to potential users, will improve not only the geotechnical model, but also the study and optimization of the resources.

This analysis contributes on the proposal of the type of foundations to be used whit respect to the influence of these factors on the occupation, what will allow to identify among other factors the main constraints when it comes to an installation of buildings.

These units are ongoing the subject of a detailed geological, geotechnical and geophysical characterization for the elaboration the geotechnical cartography, under Task 196, SASSCAL (Southern African Science Service Centre for Climate Change and Adaptive Land Use) and to update this information.

\section{ACKNOWLEDGEMENTS}

We would like to thanks to Geology Department of the Sciences Faculty of Agostinho Neto University, SASSCAL and this project would have been impossible too, without the support of many bibliographic collections and reports from LEA, (Angolan Engineering Laboratory) and construction companies GEOTECNICA, GENOPA, GRINER, MOTA-ENGIL, ODEBRECHT, QUEIRÓIS GALVÃO, SOARES DA COSTA, SOMAGUE, SONANGOL, TECNASOL and TEIXEIRA DUARTE. 


\section{REFERENCES}

[1]. Almeida, I. M. (1991) Características geotécnicas dos solos de Lisboa. Dissertação de Doutoramento na Especialidade de Geotecnia, Universidade de Lisboa, 391p.

[2]. Câmara, K.R. R.and. Pereira, A.C. (2005) Análise de Perfis de Sondagem SPT e Caracterização Geotécnica de Solos do Município de Natal. Holos, Ano 21, Maio/2005

[3]. http://www2.ifrn.edu.br/ojs/index.php/HOLOS/article/viewFile/56/62

[4]. Cavalcante, E.H (2002) Investigação teórico-experimental sobre o SPT.:1-353.

[5]. Coelho, A.G. (1980) A Cartografia Geotécnica no planeamento regional e urbano. Experiência de aplicação na região de Setúbal. Tese para especialista do LNEC, Departamento de Geotecnia / Núcleo de Prospecção, Lisboa, LNEC, 157p.

[6]. Folle, D. (2002) O estudo geoestatistico de sondagens spt para geração de mapas auxiliares em obras de engenharia; 179 pág.

[7]. Lopes, I.M.F. (2001)Avaliação das condições geológicas e geotécnicas para a caracterização do risco sísmico aplicação à colina do Castelo de S. Jorge; in., 2001, vol Master, p 238.

[8]. Marques F.M.S. (1988) Contribuição para o conhecimento geológico e geotécnico do território de macau; in: Departamento de Geologia, Faculdade de Ciências. Universidade de Lisboa,, p 184 p.

[9]. Pires G.J.P.T. (2007) Caracterização geológica e geotécnica dos solos de Luanda para o Ordenamento do Território; Departamento de Geologia. Universidade de Lisboa, , vol Master, p 217.

[10]. Pires G.J.P.T and Fernandez, H.M. (2016).Modelación de la aptitud ingeniero-geológica de los suelos de la ciudad de Luanda. Revista Minería y Geología / v.32 n.2 / abril-junio / p. 17-34,

[11]. Riccardi, L.R. (1957) Fundações com estacas de betão armado moldadas no terreno, para os edifícios da avenida marginal; in Engenharia Ld (ed): Jornada de Estradas DSOPT de Angola Luanda, vol p11p.

[12]. Vallejo, L.I.G., Mercedes; Ortuño, L., Oteo,C. (2002) Ingeniería geológica; in Pearson Educacíon S.A.(ed). Madrid, p 744. 